\title{
Skurðmeðferð lungnameinvarpa - yfirlitsgrein um ábendingar og árangur meðferðar
}

Halla Viðarsdóttir¹ læknir, Páll Helgi Möller²,4 læknir, Tómas Guðbjartsson,4 læknir

\section{ÁGRIP}

Á Íslandi greinist priðji hver einstaklingur með krabbamein á lífsleiðinni. Illkynja sjúkdómar um fjórðungur dánarmeina og eingöngu hjarta- og æðasjúkdómar eru algengari dánarorsök. Um priðjungur krabbameinssjúklinga greinist með meinvörp í lungum sem er ein algengasta staðsetning meinvarpa. Hjá sumum pessara sjúklinga getur komið til greina að fjarlægja meinvörpin með skurðaðgerð í peim tilgangi að bæta lifun. Í pessari yfirlitsgrein er farið yfir helstu ábendingar fyrir brottnámi lungnameinvarpa, rannsóknir fyrir aðgerð og árangur aðgerða. Greinin er ætluð breiðum hópi lækna og er byggt á nýjustu pekkingu og vísað til islenskra rannsókna.
'Skurðdeild Sjúkrahússins i Helsingborg, Svípjóð ${ }^{2}$ skurðlækningadeild ${ }^{3}$ hjarta- og lungnaskurðdeild Landspítala, ${ }^{4}$ æeknadeild Háskóla Íslands.

Fyrirspurnir: Halla Viðarsdóttir halla.vidarsdottir@ skane.se 28. september 2012, sampykkt til birtingar

20. febrúar 2013.

\begin{abstract}
Aðferðafræði
Leitað var að heimildum í PubMed-gagnagrunninum undir leitarorðunum pulmonary metastasectomy, pulmonary resection og pulmonary metastases. Einungis var stuðst við vísindagreinar á ensku. Engar framskyggnar slembivalsrannsóknir fundust en sérstaklega var stuðst við greinabálk um skurðmeðferð lungnameinvarpa sem birtist í Journal of Thoracic Oncology 2010 og var samstarfsverkefni á vegum European Society of Thoracic Surgeons.
\end{abstract}

\section{Ábendingar og val sjúklinga fyrir aðgerð}

Brottnám lungnameinvarpa hefur verið reynt við ýmis krabbamein en pó aðallega við lungnameinvörp sarkmeina, ristil- og endaparmskrabbameins, nýrnafrumukrabbameins og kímfrumuæxla (germ cell tumours). Framan af var árangur pessara aðgerða lítið rannsakaður en á síðustu árum hefur fjöldi rannsókna sýnt fram á góðan árangur, eða á bilinu 30 til 70\% 5 ára lifun fyrir hinar ýmsu gerðir æxla. ${ }^{1}$ Fyrsta rannsókn á árangri skurðmeðferðar við lungnameinvörpum birtist árið 1947, en par var jafnframt getið um hvaða sjúklingar gætu hugsanlega haft gagn af henni. ${ }^{2}$ Árið 1965 birtu Thomford og Clagett endurbættar ábendingar fyrir skurðmeðferð sem enn eru í fullu gildi með lítilsháttar breytingum. ${ }^{3}$ Samkvæmt peim á skurðaðgerð við pegar: a) frumæxli er skurðtækt, b) meinvörp eru ekki til staðar utan lungna (undantekning eru skurðtæk lifrarmeinvörp ristil- og endaparmskrabbameins), c) pað er tæknilega framkvæmanlegt að fjarlægja lungnameinvörpin, d) áhætta tengd aðgerð er ásættanleg fyrir sjúklinginn og e) önnur læknandi meðferð er ekki í boði. ${ }^{3}$

\section{Tíoni og greining}

Lungu eru ásamt lifur, beinum og heila pau líffæri sem krabbamein dreifa sér oftast til. Eins og sést í töflu I er tíðni lungnameinvarpa mismunandi eftir krabbameinum og er hún hæst fyrir sarkmein, eistnakrabbamein og sortuæxli. ${ }^{4}$ Líkur á pví að hnútur í lunga sé meinvarp fer eftir tegund frumæxlis. Ef upprunalega æxlið er sarkmein eða sortuæxli er tífalt líklegra að um sé að ræða meinvarp en lungnakrabbamein og um helmingslíkur ef frumæxlið er ristil- eða endaparmskrabbamein. ${ }^{5}$ Lungnameinvörp geta valdið einkennum eins og hósta og brjóstverk. Mun algengara er pó að sjúklingar séu án einkenna og greinist við eftirlit í kjölfar meðferðar á frumæxli eða pegar gerðar eru myndrannsóknir vegna óskyldra sjúkdóma. Í íslenskri rannsókn á 81 sjúklingi sem gekkst undir brottnám á lungnameinvörpum á árunum 1984 til 2008 voru 81,5\% án einkenna, og greindust langflestir peirra við krabbameinseftirlit par sem gerðar voru tölvusneiðmyndir (TS) eða röntgenmyndir af lungum. ${ }^{6}$

Tafla I. Tíðni (\%) lungnameinvarpa fyrir helstu æxlistegundir. ${ }^{4}$

\begin{tabular}{lc}
\hline Beinsarkmein & 75 \\
\hline Eistnakrabbamein & $70-80$ \\
\hline Sortuæxli & $60-80$ \\
\hline Brjóstakrabbamein & 60 \\
\hline Nýrnakrabbamein & $50-75$ \\
\hline Ristil- og endaparmskrabbamein & $20-43$ \\
\hline Pvagblöðrukrabbamein & $25-30$ \\
\hline Lungnakrabbamein & $20-30$ \\
\hline Höfuð- og hálskrabbamein & $13-40$
\end{tabular}




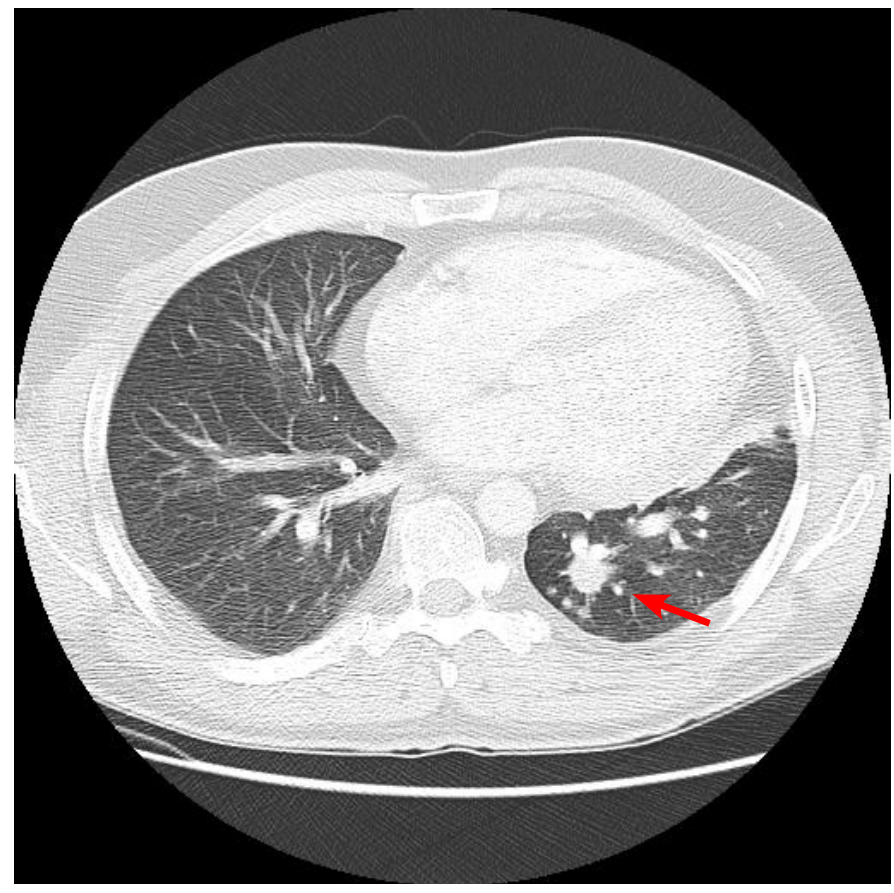

Mynd 1. Tölvusneiððmynd sem sýnir 3,5 cm meinvarp (ör) frá ristilkrabbameini. Sjúklingur gekkst undir blađnám par sem æxlið var of miðlægt í lunganu til pess að hægt væri að fjarlægja pað með fleyg- eða geiraskurði.

Almennt er litið svo á að fyrirferð eða hnútur í lunga hjá einstaklingi sem áður hefur greinst með krabbamein sé meinvarp uns annað sannast. Pessa sjúklinga verður pví að rannsaka nánar til að staðfesta að um meinvarp sé að ræða en ekki góðkynja hnút eða lungnakrabbamein. TS af brjóstholi (mynd 1) er lykilrannsókn í pessu tilliti en næmi hennar er hád stærð hnúta og er allt að 95\% fyrir hnúta sem eru stærri en $6 \mathrm{~mm}$ í pvermál. ${ }^{7}$ Í nýlegri samantekt Detterbeck og félaga er mælt með tölvusneiðmyndum sem eru ekki eldri en fjögurra vikna gamlar áður en aðgerð er framkvæmd. Yfirleitt dugar hefðbundin TS-rannsókn en ávinningur af háskerpu TS-rannsókn pykir ekki sannaður við leit að meinvörpum. ${ }^{8}$ Erlendis er víða gerð jáeindaskönnun (positronemission tomography, PET) en hún bætir yfirleitt litlu við TS pegar kemur að greiningu lungnameinvarpa, enda næmi einungis $30 \%$ fyrir hnúta undir $1 \mathrm{~cm}$ að stærð. Jáeindaskönnun kemur pví fyrst og fremst að gagni við að útiloka meinvörp utan lungna og í miðmæti. ${ }^{9} 10$ Pannig reyndust 15\% sjúklinga sem fóru í jáeindaskönnun fyrir fyrirhugaða aðgerð á lungnameinvörpum með sjúkdóm sem hafði dreift sér utan brjósthols og $2 \%$ höfðu meinvörp í miðmætiseitlum. ${ }^{9}$ Í annarri rannsókn reyndust 9\% sjúklinga sem höfðu lungnameinvörp frá sortuæxli vera með meinvörp utan brjósthols. ${ }^{11}$ Jáeindaskanni er ekki til hér á landi en sjúklingar eru sendir erlendis í rannsóknina ef pörf er talin á.

Tafla II. Helstu rannsóknir til mats og undirbúnings aðgerðar.

\begin{tabular}{l|l} 
Stigun sjúkdóms & Líkamlegt ástand \\
\hline Tölvusneiðmynd, ómun, beinaskann, jáeindaskann & Blásturspróf \\
\hline Berkjuspeglun & Hjartalínurit \\
\hline $\begin{array}{l}\text { Sértækar rannsóknir eins og segulómun og } \\
\text { ristilspeglun }\end{array}$ & Hjartaómun \\
\hline
\end{tabular}

Tafla III. Karnofsky-skali til að meta almennt ástand sjúklings.

\begin{tabular}{|c|c|c|}
\hline \multirow{3}{*}{$\begin{array}{l}\text { Eðlileg færni við } \\
\text { athafnir og vinnu; } \\
\text { engin pörf fyrir } \\
\text { aðstoð }\end{array}$} & 100 & Eðlileg færni, engin einkenni sjúkdóms \\
\hline & 90 & $\begin{array}{l}\text { Eðlileg færni, minniháttar einkenni og teikn um } \\
\text { sjúkdóm }\end{array}$ \\
\hline & 80 & $\begin{array}{l}\text { Eðlileg færni með áreynslu, nokkur einkenni og } \\
\text { teikn um sjúkdóm }\end{array}$ \\
\hline \multirow{3}{*}{$\begin{array}{l}\text { Ófær um að } \\
\text { stunda vinnu; } \\
\text { fær um að búa } \\
\text { heima og sjá um } \\
\text { persónulegar } \\
\text { parfir; mismikil } \\
\text { pörf fyrir aðstoð }\end{array}$} & 70 & $\begin{array}{l}\text { Sér um athafnir daglegs lífs, ófær um að stunda } \\
\text { vinnu }\end{array}$ \\
\hline & 60 & $\begin{array}{l}\text { Parfnast einstaka sinnum aðstoðar en annars } \\
\text { fær um að sinna persónulegum pörfum }\end{array}$ \\
\hline & 50 & $\begin{array}{l}\text { Parfnast töluverðar aðstoðar og tíðrar } \\
\text { læknispjónustu }\end{array}$ \\
\hline \multirow{5}{*}{$\begin{array}{l}\text { Ófær um ađ sjá } \\
\text { um sig; parfnast } \\
\text { sjúkrahús- } \\
\text { umönnunar; } \\
\text { sjúkdómur versnar } \\
\text { hratt. }\end{array}$} & 40 & Óvirkur, parf sérstaka umönnun og aðstoð \\
\hline & 30 & $\begin{array}{l}\text { Mjög óvirkur, parfnast innlagnar á sjúkrahús en } \\
\text { er ekki deyjandi }\end{array}$ \\
\hline & 20 & $\begin{array}{l}\text { Mjög veikur, sjúkrahúsinnlögn nauðsynleg, virk } \\
\text { stuðningsmeðferð nauðsynleg }\end{array}$ \\
\hline & 10 & Dauðvona \\
\hline & 0 & Látinn \\
\hline
\end{tabular}

\section{Undirbúningur fyrir skurðað̀gerð}

Áður en tekin er ákvörðun um brottnám lungnameinvarpa parf fjölda rannsókna og eru pær helstu sýndar í töflu II. Myndrannsóknir eru notaðar til að meta hvort lungnameinvörpin séu skurðtæk en einnig verður að útiloka að sjúkdómurinn hafi dreift sér til annarra líffæra en lungna. Fengnar eru TS af kviðarholi, par sem sérstaklega er litið á lifur og nýrnahettur, TS af heila og beinaskann eða segulómun af beinum. Berkjuspeglun er gjarnan framkvæmd, sérstaklega ef meinvörp eru staðsett nálægt miðju lungans. Sérhæfðari rannsóknir eins og ristilspeglun hjá sjúklingum með fyrri sögu um ristil- og endaparmskrabbamein koma til greina til að meta hvort krabbameinið hafi tekið sig upp. Auk rannsókna til stigunar er mikilvægt að meta ástand hjarta og lungna fyrir hugsanlega aðgerð. Öndunarmæling (spirometry), og pá sérstaklega fráblástursgeta á sekúndu $\left(\mathrm{FEV}_{1}\right.$, forced expiratory volume in 1 second), veitir mikilvægar upplýsingar um ástand lungna og áhættu við aðgerð. ${ }^{12}$ Einnig er fengið hjartalínurit og eftir atvikum hjartaómun og polpróf með mælingu á hámarkssúrefnisupptöku $\left(\mathrm{VO}_{2}\right.$ max, maximal oxygen uptake) (tafla II). Einnig er hægt að meta almennt ástand sjúklings og má gera pað með Karnofsky-skala sem metur færni sjúklingsins ( $100=$ eðlileg færni og $0=$ látinn) (tafla III).
A

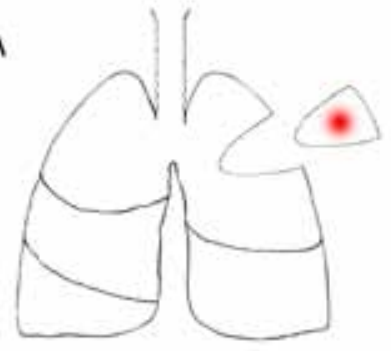

B

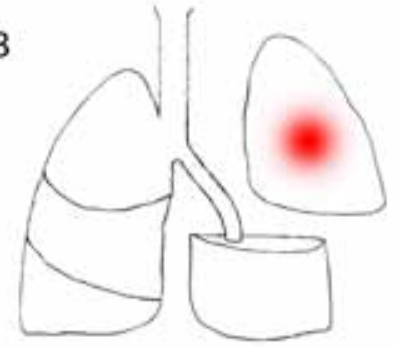

Mynd 2. Algengustu tegundir skurðaðgerða við lungnameinvörpum: A) fleygskurður og B) blađnám. Mynd: Bjarni bór Pétursson. 


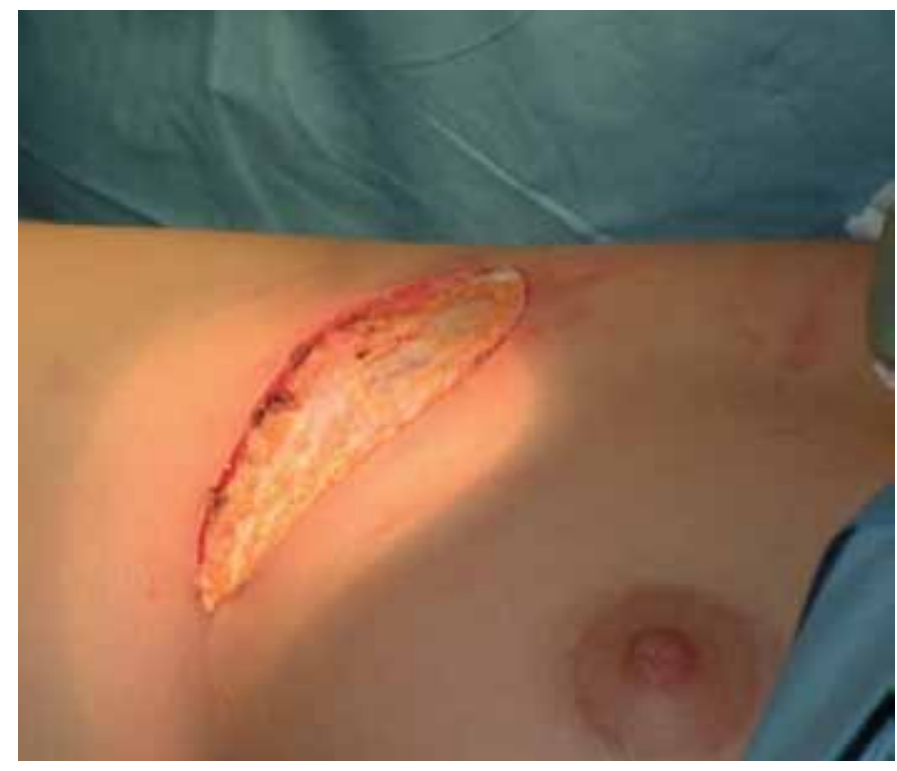

Mynd 3. Brjóstholsskurður. Mynd: Tómas Guðbjartsson.

\section{Meinvörp í miðmætis- eða porteitlum}

Meinvörp í miðmæti og lungnaporti (hilus) eru algeng hjá sjúklingum með lungnameinvörp en í nýlegum rannsóknum er tíðnin á bilinu 14-33\%.13 Eitlameinvörp eru slæmt teikn hvað varðar horfur en ekki hefur verið sýnt fram á að brottnám á eitlum bæti lifun sjúklinga. ${ }^{14-16}$ Einnig er umdeilt hvort fjarlægja eigi lungnameinvörp hafi krabbameinið borist í miðmætiseitla. ${ }^{13}$ Stigun fyrir aðgerð er oftast framkvæmd með miðmætisspeglun (mediastinoscopy) par sem tekin eru sýni úr eitlum. Einnig er hægt að ná sýni með ómun í gegnum berkjuspeglun (endoscopic bronchial ultrasound, EBUS) eða vélindaspeglun (endoscopic ultrasound, EUS). ${ }^{13}$ Í aðgerð er æskilegt að taka sýni úr eða fjarlægja eitla sem eru í sama lunga og meinvarpið, en einnig eitla sem er að finna í miðmæti peim megin sem æxlið er. Sýnatöku úr eitlum er oft ábótavant, en einungis voru tekin sýni úr eitlum í 4,6\% tilfella í gagnagrunni International Registry of Lung Metastases (IRLM) sem náði til 5206 sjúklinga. ${ }^{17}$ Í íslensku rannsókninni voru eitlar fjarlægðir í aðgerð hjá priðjungi sjúklinga en miðmætisspeglun var aðeins framkvæmd í einu tilfelli. ${ }^{6}$

\section{Tegundir skurðaðgerða}

Lungnameinvörp eru oftast fjarlægð með fleygskurði (wedge resection ) (mynd 2) og er hlutfallið 56-82\% í erlendum rannsóknum. ${ }^{17-19}$ Hér á landi er hlutfall fleygskurða í kringum $60 \%$ en blaðnám (lobectomy) (mynd 2) er framkvæmt í tæplega priðjungi tilfella, sem er frekar hátt hlutfall. ${ }^{6}$ Blaðnám hentar vel pegar æxli liggur miðlægt í lunga eða pegar fleiri en eitt meinvarp er að finna í sama lungnablaði. Við miðlæg æxli má pó stundum framkvæma geiraskurð (segmentectomy). Einnig getur komið til greina að fjarlægja allt lungað (pneumonectomy) pegar meinvarp teygir sig á milli blaða í miðju lungans. Slík meðferð er pó umdeild. ${ }^{20}$ Ástæður fyrir pví að reynt er að forðast lungnabrottnám er há tíðni fylgikvilla og að langtímahorfur eru lakar. Pannig var 5 ára lifun pessara sjúklinga aðeins 20\% í IRLM rannsókninni, en 3\% sjúklinga höfðu gengist undir lungnabrottnám sem er svipað hlutfall og hér á landi. ${ }^{6,21}$

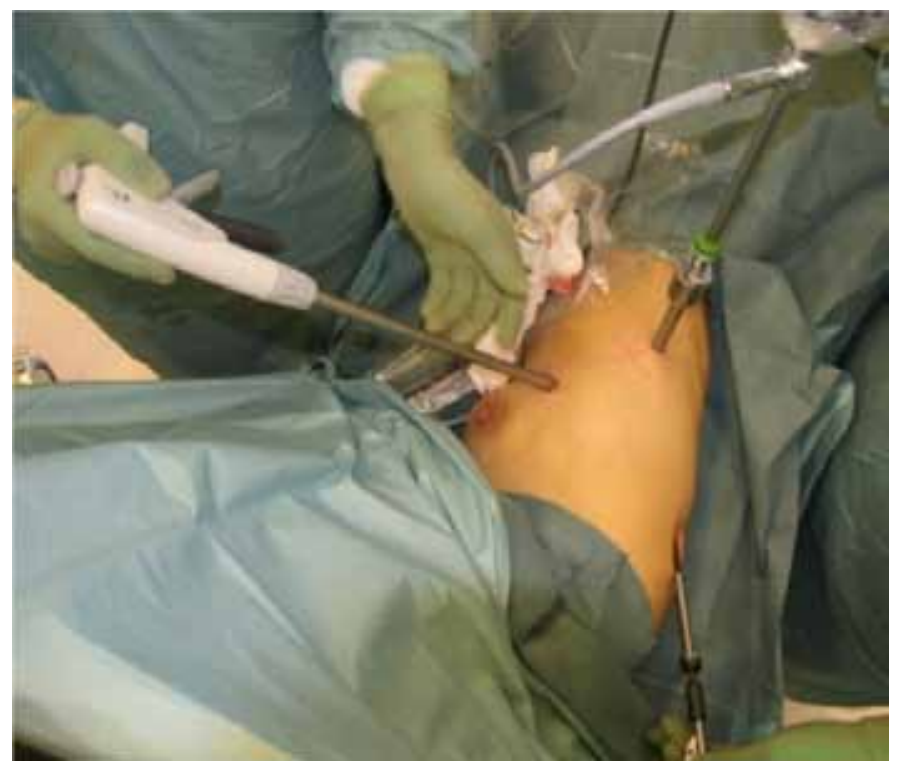

Mynd 4. Brjóstholsspeglunaraðgerð. Mynd: Tómas Guðbjartsson.

Aðgerðir á lungnameinvörpum eru oftast framkvæmdar með brjóstholsskurði par sem farið er í gegnum 4. eða 5. rifjabil (mynd 3). Allt lungað er preifað og hnútar sem taldir eru meinvörp fjarlægðir. Við fleyg- eða geiraskurð er notast við heftibyssu og meinvarpið fjarlægt ásamt umlykjandi lungnavef með 1-2 cm skurðbrúnum. Mikilvægt er að skurðbrúnir séu hreinar pví annars eru horfur sjúklingsins mun lakari en ella. ${ }^{17,22,23}$ Pegar meinvörp eru staðsett í báðum lungum og talin er ábending fyrir brottnámi er oftast gerður fleygskurður í gegnum brjóstholsskurð beggja vegna, oftast með 3-6 vikna millibili. Í peim tilfellum er mælt með TS af lungum á milli aðgerða. ${ }^{24}$ Stundum kemur pó til greina að gera fleygskurð beggja vegna í sömu aðgerð og pá í gegnum bringubeinsskurð. Aðgengi að aftari hlutum lungna er pá oft síðra en við brjóstholsskurð. ${ }^{1}$

Á síðustu árum hefur færst í vöxt að fjarlægja lungnameinvörp með brjóstholsspeglun (video assisted thoracosocpic surgery, VATS) (mynd 4). Við pessar aðgerðir eru skurðir minni en við brjóstholsskurð og sjúklingar pví fljótari að jafna sig eftir aðgerðina. ${ }^{25}$ Með pessari aðferð er auðvelt að fjarlægja meinvörp nálægt yfirborði lungans en erfiðara er að eiga við meinvörp sem staðsett eru dýpra í lunganu, enda ekki hægt að preifa lungað eins og við opna aðgerð. Petta takmarkar notagildi speglunaraðgerða en talið er að allt að priðjungur sjúklinga hafi preifanlega hnúta sem ekki sjást á TS, og að helmingur peirra sé illkynja. ${ }^{26,27}$ Pótt rannsóknir sýni sambærilega lifun og tíðni endurkomu krabbameins og við opna aðgerð, ${ }^{25}$ eru margir sem telja að brjóstholsspeglunaraðgerð eigi aðeins að beita í undantekningartilfellum hjá sjúklingum með lungnameinvörp. ${ }^{24,26,27}$ Hér á landi gengust aðeins fjórir sjúklingar af 81 undir slíka aðgerð á tímabiliinu 1984-2008. ${ }^{6}$

\section{Endurtekin lungnameinvörp}

Sjúklingar sem greinast aftur með lungnameinvörp geta í völdum tilvikum komið til greina í enduraðgerð svo fremi sem viðmið Thomford og Clagett eru uppfyllt. ${ }^{3}$ Rannsóknir á árangri end- 
uraðgerðar eru af skornum skammti en í tveimur rannsóknum á lungnameinvörpum frá ristil- og endaparmskrabbameini mældist 5 ára lifun $25 \%$ og $54 \% .^{28,29}$ Enn betri árangri hefur verið lýst hjá sjúklingum með sarkmein en par var 5 ára lifun $69 \%$ eftir endurtekið brottnám. ${ }^{23}$

\section{Eftirlit eftir skurðaðgerð}

Endurkoma krabbameins eftir brottnám á lungnameinvörpum er algeng. Í IRLM-rannsókninni fengu til dæmis 53\% sjúklinga par sem náðist að fjarlægja allan æxlisvöxt endurtekin meinvörp. Breytilegt er á milli stofnana hvernig eftirliti pessara sjúklinga er háttað eftir aðgerð, enda vantar rannsóknir á pví hvernig best er að haga slíku eftirliti. Tíðni endurtekinna lungnameinvarpa var mismunandi eftir tegund frumæxlis og var hæst fyrir sarkmein eða í tveimur tilfellum af premur. ${ }^{17}$ Mikilvægt er að greina ný meinvörp tímanlega par sem endurtekið brottnám getur komið til greina î vissum tilfellum. Í nýlegri yfirlitsgrein Detterbeck og félaga var mælt með eftirliti og TS á lungum á 6 mánaða fresti fyrstu tvö árin eftir brottnám og síðan árlega í 5 ár ef lungað var preifað í aðgerð. Hafi aðgerðin hins vegar verið gerð með speglunartækni og lungað ekki preifað er mælt með péttara eftirliti. ${ }^{8}$

\section{Önnur úrræði en skurðaðgerð}

Í sumum tilvikum eru sjúklingar ekki taldir pola skurðagerð, til dæmis vegna skertrar lungnastarfsemi eða peir ekki taldir uppfylla skilyrði brottnáms vegna dreifðra lungnameinvarpa. Í slíkum tilvikum getur komið til greina að beita staðbundinni meðferð með rafbrennslu (radiofrequency ablation), örbylgjum (microwave ablation) eða kælimeðferð (cryoablation). Einnig er í vaxandi mæli beitt hnitmiðaðri geislameðferð (sterotactic radiosurgery) við lungnameinvörp. ${ }^{30}$ Pessar aðferðir hafa fyrst og fremst verið notaðar á sjúklinga með óskurðtæk meinvörp eða pegar sjúklingi er ekki treyst í aðgerð. ${ }^{30}$

Við rafbrennslu er rafskauti komið fyrir í æxlinu með aðstoð ómunar eða TS og rafstraumur notaður til að brenna æxlið. ${ }^{30}$ Lungnameinvörp henta vel til brennslu pví loft í nálægum lungnavef einangra orkuna í æxlinu. Aðferðin hentar hins vegar ekki við meinvörp sem eru stærri en $3,5 \mathrm{~cm} .{ }^{30}$ Rafbrennsla er almennt talin áhættulítil meðferð en tæplega helmingur sjúklinga fær loftbrjóst sem í rúmlega helmingi tilfella parf að meðhöndla með brjóstholskera. ${ }^{31}$ Við örbylgjumeðferð er skauti komið fyrir í æxlinu. Rafsegulbylgjur eru síðan notaðar til að örva vatnssameindir í vefnum sem valda núningi og hitamyndun sem drepur æxlisfrumurnar..$^{30}$ Örbylgjumeðferð hentar oft betur en rafbrennsla par sem leiðni rafstraums er takmörkuð í loftríkum vef eins og lunga. Auk pess getur hitaleiðni frá rafskautum verið skert vegna kolamyndunar umhverfis pau. Við kælimeðferð er komið fyrir nál og köldu argonlofti hleypt í æxlið. Við petta sundrast æxlisfrumurnar par sem ískristallar myndast í og utan æxlisfrumanna. ${ }^{30}$ Líkt og við rafbrennslu er hægt að framkvæma örbylgju- og kælimeðferð með ástungu í gegnum brjóstvegg og er pá ómskoðun eða TS notaðar til að staðsetja æxlið. Með hnitmiðaðari geislameðferð er unnt að gefa stærri geislaskammt á sjálft æxlið en valda um leið minni geislaskemmdum á nærliggjandi vefjum..$^{30}$ Í nýlegri rannsókn var

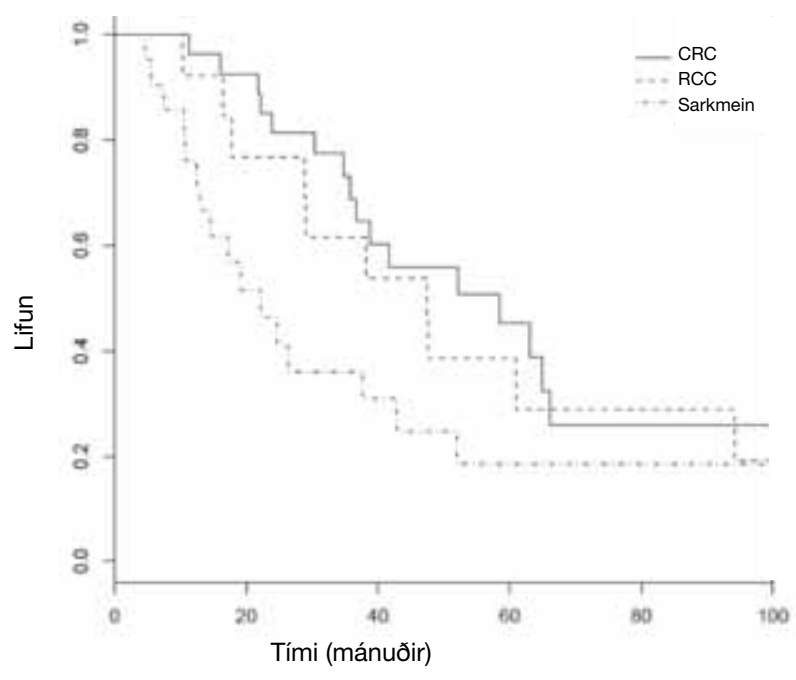

\begin{tabular}{lllllll} 
Fjöldi i áhættu & \multicolumn{1}{l}{} \\
\hline CRC & 27 & 25 & 14 & 9 & 5 & 3 \\
\hline RCC & 13 & 11 & 8 & 4 & 4 & 3 \\
\hline Sarkmein & 21 & 11 & 7 & 4 & 4 & 4 \\
\hline
\end{tabular}

Mynd 5. Lifun (Kaplan-Meier) eftir brottnám priggja algengustu lungnameinvarpa á Íslandi 1984-2008, fyrir ristil-og endaparmskrabbamein (CRC, colorectal carinoma), nýrnafrumukrabbamein (RCC, renal cell carcinoma) og sarkmein. Mynd er fengin úr heimild 6.

tveggja ára lifun um 50\% og alvarlegur geislaskaði greindist aðeins hjá $2,6 \%$ sjúklinga. ${ }^{32}$

\section{Krabbamein bar sem lungnabrottnám kemur til greina}

Brottnámi hefur verið beitt við lungnameinvörp ýmissa krabbameina en skurðaðgerð er best rannsökuð fyrir ristil- og endaparmskrabbamein, sarkmein og nýrnafrumukrabbamein, en einnig eistnakrabbamein, sortuæxli og brjóstakrabbamein. Hér verður stuttlega rakin faraldsfræði pessara krabbameina með áherslu á árangur lungnaskurðaðgerða og forspárpætti lifunar.

\section{Ristil- og endaparmskrabbamein}

Ristilkrabbamein er priðja algengasta krabbameinið hjá körlum á Íslandi og fjórða algengasta krabbameinið hjá konum. Í íslenskri rannsókn sem tók til áranna 1955-2004 reyndist tæpur fjórðungur $(22,1 \%)$ sjúklinga vera með fjarmeinvörp við greiningu. ${ }^{33}$ Algengust eru meinvörp í lífhimnu, lifur og lungum. ${ }^{34}$ Par sem stór hluti pessara sjúklinga eru með meinvörp í fleiri en einu líffæri kemur brottnám lungnameinvarpa oftast ekki til greina. Undantekning á pessu eru skurðtæk meinvörp sem greinast samtímis í lifur og lungum. ${ }^{35}$ Margt bendir til pess að skurðaðgerð sé vannýtt meðferð hjá pessum sjúklingum, en hér á landi gengust aðeins 1,4\% sjúklinga með ristil- og endaparmskrabbamein undir brottnám á meinvörpum í lungum á 15 ára tímabili. ${ }^{6}$

Í nýlegri rannsókn sem tók til 20 rannsókna og samtals 1870 sjúklinga, létust innan við 2,5\% sjúklinga innan 30 daga (skurðdauði) og 5 ára lifun var tæplega $40 \%$ eða frá 24 til 56\%. ${ }^{22}$ Til 
samanburðar var 5 ára lifun pessara sjúklinga 45\% í íslensku rannsókninni (mynd 5). Pegar jafnframt er framkvæmt brottnám á lifrarmeinvörpum er 5 ára lifun heldur lakari eða 30-42\%. ${ }^{22}$ Petta er pó mun betri árangur en sést hjá sjúklingum sem eingöngu fá lyfjameðferð. Pannig var 5 ára lifun í rannsókn Sanoff og félaga aðeins 9,8\% en flestir pessara sjúklinga höfðu dreifð meinvörp. ${ }^{36}$

Mikilvægasti forspárpáttur lifunar er hvort næst að fjarlægja allan sjáanlegan æxlisvef. ${ }^{34}$ Æxlisvísirinn CEA (carcinoembryonic antigen) hefur einnig forspárgildi, en sé hann hækkaður fyrir aðgerð eru horfur verri og sama á við pegar mörg meinvörp eru til staðar. ${ }^{22}$ Horfur eru betri ef langur tími er frá greiningu frumæxlis að greiningu meinvarps en stærð æxlis hefur par minna að segja. $^{22,37}$

\section{Nýrnafrumukrabbamein}

Nýrnafrumukrabbamein eru tæplega 4\% allra nýgreindra krabbameina á Íslandi og er nýgengi óvíða hærra á heimsvísu. ${ }^{38}$ Rúmlega fjórðungur sjúklinga er með meinvörp við greiningu og önnur $30 \%$ greinast síðar með meinvörp, oftast í lungum. ${ }^{39}$ I íslenskri rannsókn á nýrnafrumukrabbameini sem náði til 911 sjúklinga reyndust tæp $17 \%$ sjúklinga hafa meinvörp í lungum við greiningu (synchronous metastases) og tæp 36\% voru með meinvörp bundin við lungu. ${ }^{40}$ Án sértækrar meðferðar er 5 ára lifun pessara sjúklinga aðeins $11 \%{ }^{41}$ Hefðbundin lyfja- og geislameðferð dugar skammt í nýrnafrumukrabbameini og ónæmismeðferð (immunotherapy) með interferonalfa og interleukin-2 nýtist fáum pessara sjúklinga. ${ }^{42}$ Um miðjan síðasta áratug komu á markað líftæknilyf eins og tyrósín kínasa hemlar (tyrosine kinase inhibitors, TKI) sem fjölgað hefur valkostum í meðferð sjúklinga með útbreitt nýrnafrumukrabbamein. Í rannsókn sem bar saman meðferð með interferón-a og sunitiníib var meðallifun 27 borið saman við 22 mánuði og tæplega helmingur sjúklinga svaraði meðferðinni að einhverju marki. ${ }^{43}$

Brottnám er sú meðferð sem líklegust er til að bæta lifun sjúklinga með skurðtæk lungnameinvörp. Er pað stutt niðurstöðum fjölda afturskyggnra rannsókna par sem 5 ára lifun er á bilinu 2573\%.19,44,45 Í rannsókn Pfannschmidt og félaga var 5 ára heildarlifun tæp 37\% en 54\% pegar tókst að fjarlægja allan æxlisvef í lunganu. ${ }^{19}$ Í rannsókn Alt og félaga reyndust hreinar skurðbrúnir og fullt brottnám einnig mikilvægur forspárpáttur lifunar en fimm ára lifun var 73,5\% borið saman við 19\% pegar æxlisvöxtur fannst í skurðbrúnum. ${ }^{46}$ Aðrar rannsóknir hafa sýnt betri árangur ef langur tími er frá greiningu frumæxlis að greiningu meinvarps. ${ }^{19,44,45}$ I íslensku rannsókninni á lungnameinvörpum var 5 ára lifun pessa sjúklingahóps 39\% en pað kom á óvart að einungis 13 sjúklingar höfðu gengist undir brottnám lungnameinvarps á rannsóknartímabilinu. ${ }^{6}$

\section{Sarkmein i beinum}

Beinsarkmein (osteosarcoma) dreifa sér oft til lungna. Allt að fimmtungur pessara sjúklinga eru með lungnameinvörp við greiningu og er talið að $70 \%$ greinist síðar með lungnameinvörp ${ }^{47}$ en pau eru ein algengasta dánarorsök pessara sjúklinga. ${ }^{1}$ Skurðaðgerð er oft beitt enda algengt að meinvörp séu bundin við lungu. Fimm ára lifun eftir skurðaðgerð er á bilinu 29-43\%, 48,49 en endurtekið brottnám getur einnig komið til greina par sem allt að 69\% 5 ára lifun hefur verið lýst. ${ }^{23}$ Krabbameinslyf eru oft gefin fyrir aðgerð enda sýnt fram á að slík meðferð bæti lifun. ${ }^{50}$

\section{Mjúkvefjasarkmein}

Mjúkvefjasarkmein eru misleitur hópur illkynja æxla en rúmlega 50 vefjagerðum hefur verið lýst. Pessi æxli geta greinst víða í líkamanum en lungu eru algengasti staðurinn fyrir meinvörp, eða hjá $20 \%$ sjúklinga. ${ }^{51,52}$ Mjúkvefjasarkmein eru síður næm fyrir krabbameinslyfjameðferð en beinsarkmein og svara auk pess illa geislameðferð. Brottnám er pví eina læknandi meðferðin sem er í boði og hafa rannsóknir sýnt 21-50\% 5 ára lifun eftir aðgerð. ${ }^{23}$ Til samanburðar var 5 ára lifun í íslensku rannsókninni aðeins $19 \%{ }^{6}$ sem er rúmlega helmingi lægra en í nýlegri rannsókn sem tók til 97 tilfella og sýndi 50,1\% 5 ára lifun sambærilega fyrir beinog mjúkvefjasarkmein. ${ }^{23}$ Ef meira en 12 mánuðir liðu frá meðferð frumæxlis að greiningu meinvarps voru horfur betri og einnig ef skurðbrúnir voru fríar og pegar um stakt meinvarp var að ræða. ${ }^{23}$

\section{Sortuæxli}

Umdeilt er hvort brottnám á meinvörpum sortuæxla í lungum eigi rétt á sér. Flestir sjúklingar sem greindir eru með meinvörp í lungum hafa útbreidd meinvörp en pá er miðgildi lifunar aðeins 8 mánuðir og fimm ára lifun undir $5 \% .{ }^{53}$ Pví kemur aðeins lítill hluti sjúklinga til greina fyrir skurðaðgerð. Hjá sjúklingum með meinvörp takmörkuð við lungu er árangur hins vegar mun betri, til dæmis var 5 ára lifun eftir brottnám í rannsókn Schuhan og félaga 35\%, miðgildi lifunar 18 mánuðir. Karlar höfðu betri horfur en konur og reyndist pað eini sjálfstæði forspárpáttur lifunar. ${ }^{54}$ Í annarri rannsókn var 5 ára lifun $27 \%$ borið saman við $3 \%$ hjá peim sem fengu aðra meðferð $ð^{55}$ og í IRLM-gagnagrunninum var 5 ára lifun $22 \%$ og $16 \%$ eftir 10 ár. Í henni reyndist lifun verri hjá sjúklingum sem greindust með meinvörp innan 36 mánaða frá greiningu sortumeins og hjá peim sem höfðu mörg meinvörp. ${ }^{17}$

\section{Brjóstakrabbamein}

Brjóstakrabbamein er algengasta krabbameinið sem greinist í íslenskum konum og greinast um 190 konur með brjóstakrabbamein á ári á Íslandi. ${ }^{38}$ Aðeins lítill hluti sjúklinga með dreifðan sjúkdóm eru með meinvörp bundin við lungu. Pannig reyndust aðeins $0,4 \%$ brjóstakrabbameinssjúklinga í stórri rannsókn frá Mayo-sjúkrahúsinu í Bandaríkjunum hafa meinvörp sem bundin voru við lungu. ${ }^{56}$ Líkt og fyrir sortuæxli er skurðaðgerð í meðferð lungnameinvarpa umdeild, jafnvel pótt rannsóknir hafi náð að sýna 5 ára lifun á bilinu 30-45\%. ${ }^{57,58}$ Séu hormóna- og HER-2 viðtakar til staðar virðist pað bæta lifun ${ }^{58}$ en fjöldi meinvarpa, staðsetning peirra og tími frá greiningu frumæxlis að greiningu meinvarps skiptir minna máli. ${ }^{57}$ Í áđurnefndri rannsókn frá Mayosjúkrahúsinu var 5 ára lifun 35,6\% pegar náðist að fjarlægja meinvörpin í heild sinni en 42,1\% hjá hinum. Pessi niðurstaða var ekki talin rökstyðja gagnsemi skurðaðgerða ${ }^{56}$ líkt og IRLM-rannsóknin gerði, par sem 5 ára lifun var 38\% fyrir sjúklinga par sem allur æxlisvefur var fjarlægður og 18\% hjá peim par sem ekki náðist að fjarlægja allan æxlisvef í lungum. ${ }^{59}$

\section{Eistnakrabbamein}

Eistnakrabbamein er algengasta krabbameinið sem greinist í íslenskum körlum á aldrinum 25-45 ára. ${ }^{38}$ Eistnakrabbamein eru flokkuð annars vegar í sáðfrumukrabbamein (seminomatous) og hins vegar í eistnakrabbamein önnur en sáðfrumukrabbamein (non-seminomatous). Meinvörp eru algengust í aftanskinueitlum og 
lungum en í íslenskri rannsókn voru 21,6\% sjúklinga með meinvörp við greiningu og voru $13,4 \%$ með meinvörp í aftanskinueitlum og 7,3\% með fjarmeinvörp. ${ }^{60}$ Eistnakrabbamein svarar mjög vel krabbameinslyfjum jafnvel pótt fjarmeinvörp séu til staðar. ${ }^{61}$ Horfur pessara sjúklinga eru pví yfirleitt ágætar en hér á landi læknast yfir $95 \%$ sjúklinga af sjúkdómnum. ${ }^{60}$

Meðferð eistnakrabbameins felst í blöndu krabbameinslyfja sem innihalda meðal annars cisplatín en í allt að 30\% tilfella næst ekki að lækna meinið með peim. Ef lungnameinvörp sjást á TS eftir lyfjameðferð getur skurðaðgerð komið til greina. ${ }^{61}$ Í íslenskri rannsókn reyndust 8 af 97 sjúklingum vera með lungnameinvörp við greiningu og voru peir allir með eistnakrabbamein önnur en sáðfrumukrabbamein. ${ }^{60}$ Aðeins einn pessara sjúklinga gekkst undir lungnaaðgerð og læknaðist hann af sjúkdómnum. ${ }^{6}$ Í nýlegri samantekt á 6 rannsóknum sem tóku til 407 sjúklinga sem gengist höfðu undir brottnám á lungnameinvörpum frá einstnakrabbameini öðru en sáðfrumukrabbameini var dánarhlutfall innan 30 daga undir 4\% og 5 ára lifun á bilinu 73-94\%. ${ }^{61}$ Rannsóknir hafa einnig sýnt betri lifun pegar fjöldi meinvarpa er undir fjórum ${ }^{62}$ og pegar hækkun á æxlisvísunum alfa fetoprotein og beta human chorionic gonadotropin (b-HCG ) er lítil. ${ }^{61}$

\section{Lokaoro}

Pegar meinvörp eru bundin við lungu getur brottnám með skurðaðgerð komið til greina. Petta á sérstaklega við um sjúklinga með stök/fá meinvörp frá sarkmeini, ristil- og endaparmskrabbameini og nýrnafrumukrabbameini. Ekki eru til framskyggnar, slembaðar rannsóknir á árangri pessara aðgerða en fjöldi afturskyggnra rannsókna hefur sýnt að lifun peirra sem gangast undir aðgerð er betri en eftir aðra meðferð. Pó er mikilvægt að hafa í huga að sjúklingar sem gangast undir aðgerð eru valinn hópur og valskekkja getur pví haft áhrif á niðurstöður samanburðarrannsókna, skurðaðgerðum í hag. Engu að síður er ljóst að brottnám lungnameinvarpa er örugg aðgerð par sem tíðni fylgikvilla er lág og innan við 1\% sjúklinga lifa ekki af aðgerðina. Mikilvægt er að vanda val á sjúklingum í aðgerð en til pess eru sameiginlegir krabbameinsfundir tilvaldir. Í dag eru slíkir fundir haldnir innan flestra sérgreina hér á landi.

\section{Heimildir}

1. Hornbech K, Ravn J, Steinbruchel DA. Current status of pulmonary metastasectomy. Eur J Cardiothorac Surg 2011; 39: 955-62.

2. Alexander J, Haight C. Pulmonary resection for solitary metastatic sarcomas and carcinomas. Surg Gynecol Obstet 1947, 85: 129-46.

3. Thomford NR, Woolner LB, Clagett OT. The Surgical Treatment of Metastatic Tumors in the Lungs. J Thorac Cardiovasc Surg 1965; 49: 357-63.

4. Hoetzenecker K, Lang G, Ankersmit HJ, Klepetko W. Pulmonary metastasectomy. European surgery 2011.

5. Rusch VW. Pulmonary metastasectomy: a moving target. J Thorac Oncol 2010; 5: S130-131

6. Vidarsdottir $\mathrm{H}$, Moller PH, Jonasson JG, Pfannschmid $\mathrm{J}$, Gudbjartsson T. Indications and surgical outcome following pulmonary metastasectomy: a nationwide study. Thorac Cardiovasc Surg 2012; 60: 383-9.

7. Diederich S, Semik M, Lentschig MG, Winter F, Scheld $\mathrm{HH}$, Roos N, et al. Helical CT of pulmonary nodules in patients with extrathoracic malignancy: CT-surgical correlation. AJR Am J Roentgenol 1999; 172: 353-60.

8. Detterbeck FC, Grodzki T, Gleeson F, Robert JH. Imaging requirements in the practice of pulmonary metastasectomy. J Thorac Oncol 2010; 5: S134-139.

9. Pastorino U, Veronesi G, Landoni C, Leon M, Picchio M, Solli PG, et al. Fluorodeoxyglucose positron emission tomography improves preoperative staging of resectable lung metastasis. J Thorac Cardiovasc Surg 2003, 126: 190610 .

10. Fortes DL, Allen MS, Lowe VJ, Shen KH, Wigle DA, Cassivi $\mathrm{SD}$, et al. The sensitivity of $18 \mathrm{~F}$-fluorodeoxyglucose positron emission tomography in the evaluation of metastatic pulmonary nodules. Eur J Cardiothorac Surg 2008; 34: 1223-7.

11. Dalrymple-Hay MJ, Rome PD, Kennedy C, Fulham M, McCaughan BC. Pulmonary metastatic melanoma -- the survival benefit associated with positron emission tomography scanning. Eur J Cardiothorac Surg 2002; 21: 611-4; discussion 614-5

12. Colice GL, Shafazand S, Griffin JP, Keenan R, Bolliger CT. Physiologic evaluation of the patient with lung cance being considered for resectional surgery: ACCP evidenced-based clinical practice guidelines (2nd edition). Chest 2007; 132: 161S-177S.

13. Garcia-Yuste M, Cassivi S, Paleru C. Thoracic lymphatic involvement in patients having pulmonary metastasectomy: incidence and the effect on prognosis. J Thorac Oncol 2010; 5: S166-169.
14. Pfannschmidt J, Klode J, Muley T, Dienemann H, Hoffmann H. Nodal involvement at the time of pulmonary metastasectomy: experiences in 245 patients. Ann Thorac Surg 2006; 81: 448-54.

15. Veronesi G, Petrella $F$, Leo F, Solli $P$, Maissoneuve $P$, Galetta D, et al. Prognostic role of lymph node involvement in lung metastasectomy. J Thorac Cardiovasc Surg 2007; 133: 967-72.

16. Okumura S, Kondo H, Tsuboi M, Nakayama H, Asamura $H$, Tsuchiya R, et al. Pulmonary resection for metastatic colorectal cancer: experiences with 159 patients. J Thorac Cardiovasc Surg 1996; 112: 867-74.

17. Long-term results of lung metastasectomy: prognostic analyses based on 5206 cases. The International Registry of Lung Metastases. J Thorac Cardiovasc Surg 1997; 113: 37-49.

18. Hornbech K, Ravn J, Steinbruchel DA. Outcome after pulmonary metastasectomy: analysis of 5 years consecutive surgical resections 2002-2006. J Thorac Oncol 2011; 6: 1733 40.

19. Pfannschmidt J, Hoffmann H, Muley T, Krysa S, Trainer C, Dienemann H. Prognostic factors for survival after pulmonary resection of metastatic renal cell carcinoma. Ann Thorac Surg 2002; 74: 1653-7.

20. Migliore M, Jakovic R, Hensens A, Klepetko W. Extending surgery for pulmonary metastasectomy: what are the limits? J Thorac Oncol 2010; 5:S155-160.

21. Koong HN, Pastorino U, Ginsberg RJ. Is there a role for pneumonectomy in pulmonary etastases? International Registry of Lung Metastases. Ann Thorac Surg 1999; 68 2039-43.

22. Pfannschmidt J, Dienemann $\mathrm{H}$, Hoffmann $\mathrm{H}$ Surgical resection of pulmonary metastases from colorectal cancer: a systematic review of published series. Ann Thorac Surg 2007; 84: 324-38.

23. Kim S, Ott HC, Wright CD, Wain JC, Morse C, Gaissert $\mathrm{HA}$, et al. Pulmonary resection of metastatic sarcoma: prognostic factors associated with improved outcomes. Ann Thorac Surg 2011; 92:1780-6; discussion 1786-7.

24. Molnar TF, Gebitekin C, Turna A. What are the considerations in the surgical approach in pulmonary metastasectomy? J Thorac Oncol 2010; 5: S140-144.

25. Carballo M, Maish MS, Jaroszewski DE, Holmes CE. Video-assisted thoracic surgery (VATS) as a safe alternative for the resection of pulmonary metastases: a retrospective cohort study. J Cardiothorac Surg 2009; 4: 13.

26. Cerfolio RJ, Bryant AS, McCarty TP, Minnich DJ. A prospective study to determine the incidence of non-imaged malignant pulmonary nodules in patients who undergo metastasectomy by thoracotomy with lung palpation. Ann Thorac Surg 2011; 91: 1696-701.
27. Cerfolio RJ, McCarty T, Bryant AS. Non-imaged pulmonary nodules discovered during thoracotomy for metastasectomy by lung palpation. Eur J Cardiothorac Surg 2009; 35: 786-91; discussion 791.

28. Welter S, Jacobs J, Krbek T, Krebs B, Stamatis G. Long-term survival after repeated resection of pulmonary metastases from colorectal cancer. Ann Thorac Surg 2007; 84: 203-10.

29. Pfannschmidt J, Muley T, Hoffmann $\mathrm{H}$, Dienemann $\mathrm{H}$. Prognostic factors and survival after complete resection of pulmonary metastases from colorectal carcinoma: experiences in 167 patients. J Thorac Cardiovasc Surg 2003; 126: 732-9.

30. Venuta F, Rolle A, Anile M, Martucci N, Bis B, Rocco G. Techniques used in lung metastasectomy. J Thorac Oncol 2010; 5: S145-150

31. Steinke K, Glenn D, King J, Clark W, Zhao J, Clingan P, et al. Percutaneous imaging-guided radiofrequency ablation in patients with colorectal pulmonary metastases: 1-year follow-up. Ann Surg Oncol 2004; 11: 207-12.

32. Siva S, MacManus M, Ball D. Stereotactic radiotherapy for pulmonary oligometastases: a systematic review. J Thorac Oncol 2010; 5: 1091-9.

33. Snaebjornsson $\mathrm{P}$, Jonasson $\mathrm{L}$, Jonsson $\mathrm{T}$, Moller $\mathrm{PH}$ Theodors A, Jonasson JG. Colon cancer in Iceland--a nationwide comparative study on various pathology parameters with respect to right and left tumor location and patients age. Int J Cancer 2010; 127: 2645-53.

34. Pfannschmidt J, Hoffmann $\mathrm{H}$, Dienemann $\mathrm{H}$. Reported outcome factors for pulmonary resection in metastatic colorectal cancer. J Thorac Oncol 2010; 5: S172-178.

35. Headrick JR, Miller DL, Nagorney DM, Allen MS, Deschamps C, Trastek VF, et al. Surgical treatment of hepatic and pulmonary metastases from colon cancer. Ann Thorac Surg 2001; 71: 975-9; discussion 979-80.

36. Sanoff HK, Sargent DJ, Campbell ME, Morton RF, Fuchs CS, Ramanathan RK, et al. Five-year data and prognostic factor analysis of oxaliplatin and irinotecan combinations for advanced colorectal cancer: N9741. J Clin Oncol 2008; 26: 5721-7.

37. Kanemitsu Y, Kato T, Hirai T, Yasui K. Preoperative probability model for predicting overall survival after resection of pulmonary metastases from colorectal cancer. Br J Surg 2004; 91: 112-20.

38. Krabbamein á Íslandi - Upplýsingar úr Krabbameinsskrá fyrir tímabilið 1957-2006. Ritstj. Jónasson JG. Krabbameinsfélagið, Reykjavík 2008.

39. Hofmann HS, Neef H, Krohe K, Andreev P, Silber RE. Prognostic factors and survival after pulmonary resection of metastatic renal cell carcinoma. Eur Urol 2005; 48: 77-81; discussion 81-2. 
40. Oddsson SJ, Hardarson S, Petursdottir V, Jonsson E, Sigurdsson MI, Einarsson GV, et al. Synchronous pulmonary metastases from renal cell carcinoma--a whole nation study on prevalence and potential resectability. Scand J Surg 2012; 101: 160-5.

41. Gudbjartsson T, Hardarson S, Petursdottir V, Thoroddsen A, Magnusson J, Einarsson GV. Histological subtyping and nuclear grading of renal cell carcinoma and their implications for survival: a retrospective nation-wide study of 629 patients. Eur Urol 2005; 48: 593-600.

42. Ravaud A, Audhuy B, Gomez F, Escudier B, Lesimple T, Chevreau $C$, et al. Subcutaneous interleukin-2, interferon alfa-2a, and continuous infusion of fluorouracil in metastatic renal cell carcinoma: a multicenter phase II trial. Groupe Francais d Immunotherapie. J Clin Oncol 1998; 16: 2728-32.

43. Motzer RJ, Hutson TE, Tomczak P, Michaelson MD, Bukowski RM, Oudard S, et al. Overall survival and updated results for sunitinib compared with interferon alfa in patients with metastatic renal cell carcinoma. J Clin Oncol 2009; 27: 3584-90

44. Kanzaki R, Higashiyama M, Fujiwara A, Tokunaga T, Maeda J, Okami J, et al. Long-term results of surgical resection for pulmonary metastasis from renal cell carcinoma: a 25-year single-institution experience. Eur J Cardiothorac Surg 2011; 39: 167-72.

45. Piltz S, Meimarakis G, Wichmann MW, Hatz R, Schildber FW, Fuerst $H$. Long-term results after pulmonary resecti of renal cell carcinoma metastases. Ann Thorac Surg 2002; 73: 1082-7.
46. Alt AL, Boorian SA, Lohse CM, Costello BA, Leibovich $B C$, Blute ML. Survival after complete surgical resection of multiple metastases from renal cell carcinoma. Cancer 2011; 117: 2873-82.

47. Goorin AM, Shuster JJ, Baker A, Horowitz ME, Meyer WH, Link MP. Changing pattern of pulmonary metastases with adjuvant chemotherapy in patients with osteosarcoma: results from the multiinstitutional osteosarcoma study. J Clin Oncol 1991; 9: 600-5.

48. Suzuki $M$, Iwata $T$, Ando $S$, Iida $T$, Nakajima $T$, Ishii $T$, et al. Predictors of long-term survival with pulmonary metastasectomy for osteosarcomas and soft tissue sarcomas. J Cardiovasc Surg (Torino) 2006; 47: 603-8.

49. Briccoli A, Rocca M, Salone M, Bacci G, Ferrari S, Balladell A, et al. Resection of recurrent pulmonary metastases in patients with osteosarcoma. Cancer 2005; 104: 1721-5.

50. Antunes M, Bernardo J, Salete M, Prieto D, Eugenio L, Tavares P. Excision of pulmonary metastases of osteogenic sarcoma of the limbs. Eur J Cardiothorac Surg 1999; 15 $592-6$

51. Cormier J. Soft tissue sarcomas. Ritstj Brunicardi CF. McGraw-Hill 2010

52. Pfannschmidt J, Hoffmann $\mathrm{H}$, Schneider T, Dienemann $\mathrm{H}$. Pulmonary metastasectomy for soft tissue sarcomas: is it justified? Recent Results Cancer Res 2009; 179: 321-36.

53. Lee ML, Tomsu K, Von Eschen KB. Duration of survival for disseminated malignant melanoma: results of a metaanalysis. Melanoma Res 2000; 10: 81-92.

54. Schuhan C, Muley $\mathrm{T}$, Dienemann $\mathrm{H}$, Pfannschmidt J. Survival after pulmonary metastasectomy in patients with malignant melanoma. Thorac Cardiovasc Surg 2011; 59: $158-62$
55. Tafra L, Dale PS, Wanek LA, Ramming KP, Morton DL Resection and adjuvant immunotherapy for melanoma metastatic to the lung and thorax. J Thorac Cardiovasc Surg 1995; 110: 119-28; discussion 129.

56. McDonald ML, Deschamps C, Ilstrup DM, Allen MS, Trastek VF, Pairolero PC. Pulmonary resection for metastatic breast cancer. Ann Thorac Surg 1994; 58: 1599-602.

57. Tanaka F, Li M, Hanaoka N, Bando T, Fukuse T, Hasegawa S, Wada. Surgery for pulmonary nodules in breast cancer patients. Ann Thorac Surg 2005; 79: 1711-4; discussion 1714-5.

58. Welter S, Jacobs J, Krbek T, Totsch M, Stamatis G. Pulmonary metastases of breast cancer. When is resection indicated? Eur J Cardiothorac Surg 2008; 34: 1228-34.

59. Friedel G, Pastorino U, Ginsberg RJ, Goldstraw P, Johnston M, Pass $\mathrm{H}$, et al. Results of lung metastasectomy from breast cancer: prognostic criteria on the basis of 467 cases of the International Registry of Lung Metastases. Eur J Cardiothorac Surg 2002; 22: 335-44.

60. Orrason AW, Agnarsson BA, Geirsson G, Helgason HH, Gudbjartsson T. Krabbamein í eistum á Íslandi 2000-2009: Nýgengi og lífshorfur. Læknablaðið 2011; 97:143-8.

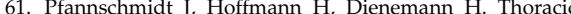
metastasectomy for nonseminomatous germ cell tumors. J Thorac Oncol 2010; 5: S182-186.

62. Kesler KA, Wilson JL, Cosgrove JA, Brooks JA, Messiha A, Fineberg NS, et al. Surgical salvage therapy for malignant intrathoracic metastases from nonseminomatous germ cell cancer of testicular origin: analysis of a single-institution experience. J Thorac Cardiovasc Surg 2005; 130: 408-15.

\section{ENGLISH SUMMARY}

\section{Pulmonary metastasectomy - a review on indications and outcome}

Vidarsdottir $\mathrm{H}^{1}$, Moller $\mathrm{PH}^{2,4}$, Gudbjartsson $\mathrm{T}^{3,4}$

In Iceland every third individual is diagnosed with malignant disease; cancer being the cause of death in one out of four individuals with only cardiovascular diseases being more common cause of death. Approximately one third of cancer patients are diagnosed with lung metastases making the lungs one of the most common metastatic site. In some of these patients a metastasectomy is a treatment option with the intention of improving survival. In this evidence-based review, the indications and outcome of pulmonary metastasectomy are discussed. This review is aimed at doctors within different specialties where Icelandic studies on pulmonary metastasectomy are referred to.

Key words: Pulmonary metastasectomy, lung metastases, indications, surgical technique, prognostic factors, survival .

Correspondence: Halla Viðarsdóttir, halla.vidarsdottir@skane.se

${ }^{1}$ Department of Surgery, Helsingborg Hospital, Helsingborg, Sweden, ${ }^{2}$ Department of Surgery, Landspitali University Hospital, ${ }^{3}$ Department of Cardiothoracic Surgery, Landspitali University Hospital, ${ }^{4}$ Faculty of Medicine, University of Iceland, Reykjavik. 